\title{
Lean Manufacturing Approach to Reduce Wastefulness During Production of Train Car-Body Using VALSAT Method
}

\section{Tuwanku Aria Auliandri and Nida Chofiya Alfiani}

Universitas Airlangga, Airlangga, Gubeng, Kota SBY, Jawa Timur 60115, Indonesia

\section{Abstract}

Based on the National Statistics Bureau, the number of train passengers in Indonesia has steadily increased; hence, it has increased demands for train car bodies. Train production in Indonesia is conducted by PT. Train Industry (INKA), Madiun. A manufacturing enterprise that processes raw materials into finished goods through a complicated process before delivering the goods to consumers. During the process, wasteful activities frequently occur and do not add any value stream. Wasteful activities extend and delay the production process, which harms the company. This

Corresponding Author: Tuwanku Aria Auliandri tuwanku@gmail.com

Received: 29 August 2018 Accepted: 18 September 2018 Published: 11 November 2018

Publishing services provided by Knowledge

(c) Tuwanku Aria Auliandri and Nida Chofiya Alfiani. This article is distributed under the terms of the Creative Commons

Attribution License, which permits unrestricted use and redistribution provided that the original author and source are credited.

Selection and Peer-review under the responsibility of the ICOI-2018 Conference Committee. research was conducted at the Fabrication Division of the train manufacture company, PT. INKA, Madiun. It is aimed to identify and minimize wasteful activities during train car body production process conducted by the Fabrication Division using Lean Manufacturing approach. Analysis on wasteful activities is conducted using Value Stream Mapping with Process Activity Mapping (PAM) and Supply Chain Response Matrix (SCRM) and calculated with VALSAT. Based on the research findings, the most wasteful activity is waiting time. Waiting time is caused by the delay in the arrival of raw materials, which causes further delay in production time, unfit machinery capability and barely-skilled labors. Based on PAM, wasteful activities, which are mostly caused by delays in non-value adding activity (NVA), took up 271.5 hours or $16.80 \%$ of total production time. Based on SCRM, total lead time of car body production until it reached the Finishing Division amounted to 131 days. After analysis, suggestions for improvement are given to minimize wasteful activities. Based on the suggestions, a decrease in NVA was achieved at $88.67 \%$ rate and lead time decreased by $15.64 \%$.

Keywords: lean manufacturing, wastefulness, Value Stream Mapping, VALSAT

\section{Introduction}

\subsection{Research background}

The number of train passengers in Indonesia has consistently increased each year. It is evidenced from a survey conducted by National Statistics Bureau (BPS) Indonesia. 
Based on the survey, from 2013 to 2014 , there was an increase of 5,125 passengers, or $17.45 \%$, and from 2015 to 2016 , there was an increase of 2,156 , or $7.938 \%$ (www. bps.go.id).The increase causes train car body demand to increase. Train production in Indonesia is conducted by one company, PT. INKA, Madiun. As the sole producer of train manufacture, PT. INKA should be able to produce trains on demand. As a manufacturing company, it processes raw materials to finished goods to be delivered to consumers; hence, it requires a complex production process. Wasteful activities frequently happen. Gasperz (2007) defined wasteful activities as the activities with no value-added provided along the value stream.

This research is conducted at Fabrication Division of PT. INKA, Madiun. PT. INKA focuses on train manufacture (freight train, passenger train, diesel train and electric train), train overhaul, local trade and train-related goods and services export and import. PT. INKA uses a make-to-order production system under a certain project duration. During the production process, wasteful activities frequently occur and cause delay in delivery time. Those wasteful activities encompass the delay from raw material suppliers, which influences processing time and delay in the schedule, delay in the procurement of consumable goods and broken machines whose components can only be bought abroad. Reworking is usually caused by non-conformity of size or fitting accuracy, human error, scrap product revision, and defects. Those exacerbate PT. INKA's delay in delivering the final products to the consumers.

Based on the background above, lean manufacturing approach allows the company to eliminate such wastefulness and improve its performance. The first step is to describe the value stream to see the whole production process in the Fabrication Division of PT. INKA, from production process and material flow to information flow. The tool that can be used to obtain such information is Value Stream Mapping (VSM). This technique identifies all value-added and non-value-added activities throughout the production stream, so wastefulness can be found, be minimized and even eliminated. By identifying and minimizing wastefulness in value stream, the lead time of production and cost can be minimized. Identifying the cause of wastefulness and where it occurs can be done by the Value Stream Analysis Tools (VALSAT) method. The wastefulness can then be eliminated with various considerations. The research process is done by direct observation and tracing corporate documents. Interviews with some employees of Fabrication Division of PT. INKA (Persero) Madiun are also conducted. The employees should have some authority, understand, and be involved directly in the production process. 


\subsection{Research problems}

1. What are the causes of wastefulness in the train car body production process in the Fabrication Division of PT. INKA (Persero) Madiun?

2. How to analyze the occurrence of wastefulness in the train car body production process in the Fabrication Division of PT. INKA (Persero) through Lean Manufacturing approach?

3. What suggestions should be provided to the Fabrication Division of PT. INKA?

\section{Theoretical Framework}

\subsection{Lean philosophy}

The lean philosophy comes from the Toyota Production System (TPS). It is an approach that focuses on activities which provide value to customers by minimizing the use of non-added-value resources commonly known as waste. Lean is designed to eliminate wastefulness throughout the production process, from designing the product, establishing supplier networks and managing the factories. The goal is to increase the products' added value by eliminating waste, reducing unnecessary work, lowering cost, producing higher quality of products and shortening lead time of production. Lean manufacturing has the main principle to minimize seven kinds of wastefulness to increase customer satisfaction (Liker, 2006).

\subsection{Wastefulness}

Based on Chase and Jacobs (2011), wastefulness, as defined by the former Toyota President, Fujio Cho, is anything beyond the minimal calculation of equipment, raw materials, parts and workers (working hours) which play their respective part in production. Wastefulness takes a lot of company resources and can be found anytime and anywhere. According to Hines and Rich (1997), wastefulness is divided into seven types, namely:

\section{Overproduction}

Overproduction is wasteful when the company produces more than consumers demand or exceeds the required amount of target.

\section{Waiting period}


Waiting period covers periods which stall the production process. In the factory, this waste occurs when the production does not move forward or is still in progress. This wastefulness affects both product and worker, as each will wait for one another.

\section{Transportation (excessive transportation)}

Transportation is the movement of goods, either material, work in process (WIP), or finished goods, which have the risk of damage, loss, delay, etc., and increase the cost without adding more value.

\section{Inappropriate processing}

Inappropriate processing includes all unnecessary activities in the production process. Inappropriate processing generally occurs if the production equipment is unkempt, less ready to use, or less perfect in terms of accuracy, flexibility, integration of automation, and so on. It causes the operators to spend more effort.

\section{Unnecessary Inventory}

This form of waste can be in the form of material inventory, work in process (WIP) goods, and finished goods, which add to expenditure and do not produce income.

\section{Unnecessary movements}

Unnecessary and excessive movements in the form of human or individual movements or equipment to the course of the production process.

\section{Defects}

Defective products are products that do not conform to factory quality standards.

\subsection{Value stream mapping (VSM)}

VSM is an important tool that can help managers understand the operational conditions they are facing and use the opportunity to improve the operational performance of the company. VSM is a symbol language and used as a technique to analyze material and information flows (Jones and Womack 2000). To describe Value Stream Mapping, there are some special process symbols, namely raw material with flow symbols, information on flow symbols, and common symbols. In Value Stream Mapping, there are two kinds of mapping, namely current state mapping as the current state of the whole production process and future state mapping, which is a map of ideal conditions of the production process desired by the company in the future. 


\subsection{Value stream mapping Tools}

Hines and Rich (1997) suggested seven tools that can be used in Value Steam Mapping, namely Process Activity Mapping (PAM), Supply Chain Responses Matrix (SCRM), Production Variety Funnel, Quality Filter Mapping, Demand Amplification Mapping (DAM), Decision Point Analysis and Physical Structure.

\subsection{Value stream analysis tools (VALSAT)}

VALSAT is a calculation tool used to perform the mapping process after weighting the occurring wasteful activities. VALSAT calculation results will be used to determine the tools which could reduce wastefulness. However, selecting more than one tool can be more useful.

\subsection{Fishbone diagram}

Fishbone diagram, or cause and effect diagram, was developed by Ishikawa in 1968. It helps examine the cause of a problem (Ishikawa, 1968). In a fishbone diagram, there are five categories that cause problems (Gasperz, 2002), namely man, method, machine, material and environment.

\section{Research Methodology}

\subsection{Research approach}

This research employed qualitative-descriptive approach. Qualitative research is a research on the condition of an object in which researchers retrieve the data directly at the source through interviews and direct observation. In contrast, descriptive study is a method used to describe or analyze a research finding, without making a wider conclusion (Sugiyono, 2005). The purpose of this descriptive study is to create a description, or illustration systematically, factually and accurately about the facts, properties and relationships between the investigated phenomena. 


\subsection{Data type and resource}

This research used primary and secondary data. Primary data were obtained directly from PT. INKA through field observation and interviews with the related parties, while the secondary data were obtained from existing sources, usually in the form of reports with table format or diagram. Secondary data can be literature study, internal company data, organizational structure and Internet data.

\subsection{Data analysis}

The technique used in this research was lean manufacturing approach with VALSAT to analyze wastefulness. There are several steps in this research, namely drawing current state mapping, analyzing the cause of wasteful activities based on the questionnaire using VALSAT tools, identifying the cause, formulating suggestions for improvement on the train car body production process, describing future state mapping, drawing conclusions and recommendations for further research.

\section{Results and Discussions}

\subsection{Analysis on wastefulness during the train car body production process}

\subsubsection{Current state mapping}

Current state mapping is the company's overall production process per day. The nontechnical production process starts from a tender arrangement by the Marketing Division, while technical production starts from designs made by the Technology Production Division. Thereafter, the PPC section makes a breakdown on the number and shape of the required part. Then, PPC sends BOM to the Logistics Division and develops working instruction (WI). There are several material flows in PT. INKA. Raw materials, in the form of steel plates and round bars, are brought from the logistics warehouse to the workshop for inspection. Next, the machines are set up to start the production process. The first stage of the train car body production process is called Detailed Part Manufacturing (DPM) to produce the smallest component of the train in numerous single parts. Some single parts are assembled into minor assays, yet have no function. 


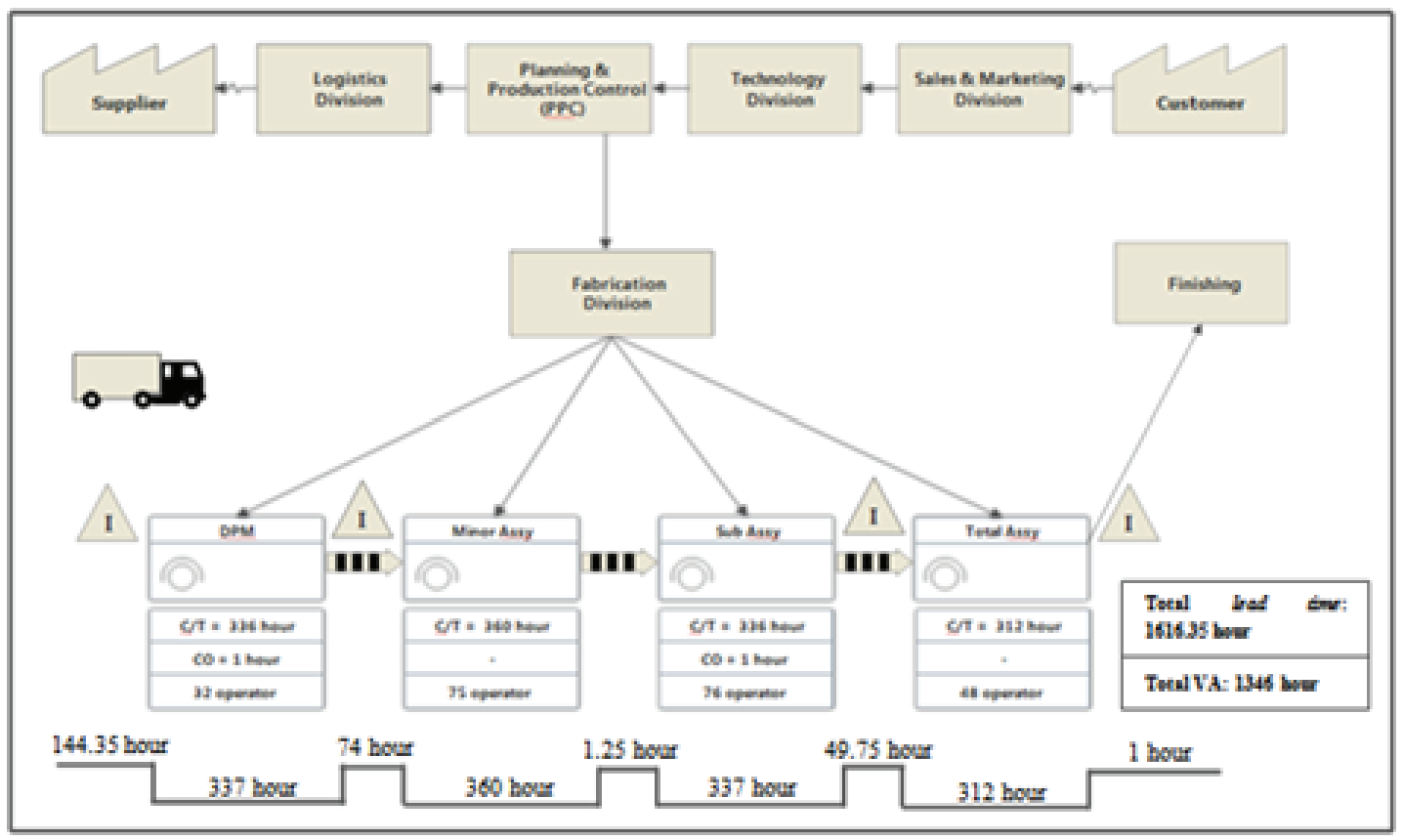

Figure 1: Current State Mapping (Source: processed from company data).

Some minor assays are then assembled into sub assays. The results of sub assay components are the main underframe, roof, sidewall and end wall which will be assembled into a train car body.

\subsubsection{Identification of wasteful activities}

Based on the calculation of the questionnaire results, the highest percentage of wasteful activities occurred during the train car body production process in the Fabrication Division was waiting time at $22.52 \%$, unnecessary inventory at $18.75 \%$, and transportation cost at $14.98 \%$. Based on the results of the interview, wasteful activity is largely caused by late arrival of raw materials, less skilled labor, inadequate engine capacity and insufficient space and means of conveyance.

\subsubsection{Selecting VALSAT tools}

Selection was conducted by weighting the VALSAT tools and calculating the average value of each waste, then multiplying it by certain weight of VALSAT tools. High value was 9, medium was 3, and low value was 1 . Based on the calculations, two tools with the highest value were used to analyze wasteful process, namely Process Activity Mapping (PAM) at 76.17 and Supply Chain Response Matrix (SCRM) at 44.1. 
TABle 1: Calculation Results of Activity Mapping Process.

\begin{tabular}{l|c|c|c|c|}
\hline Activity & Number & $\begin{array}{c}\text { Percentage } \\
(\%)\end{array}$ & $\begin{array}{c}\text { Time } \\
\text { (hours) }\end{array}$ & $\begin{array}{c}\text { Percentage } \\
(\%)\end{array}$ \\
\hline Operation & 32 & $55.17 \%$ & 1321 & $81.73 \%$ \\
\hline Transportation & 13 & $22.41 \%$ & 5.75 & $0.36 \%$ \\
\hline Inspection & 2 & $3.45 \%$ & 26 & $1.61 \%$ \\
\hline Storing & 1 & $1.72 \%$ & 24 & $1.48 \%$ \\
\hline Delay & 10 & $17.24 \%$ & 239.6 & $14.82 \%$ \\
\hline Total & 58 & & 1616.35 & \\
\hline VA & 33 & $56.90 \%$ & 1321.5 & $81.76 \%$ \\
\hline NVA & 18 & $31.03 \%$ & 271.5 & $16.80 \%$ \\
\hline NNVA & 7 & $12.07 \%$ & 23.35 & $1.44 \%$ \\
\hline Total & 58 & & 1616.35 & \\
\hline Total Time (hour) & 1616.35 & & & \\
\hline Total Distance (meter) & 1394.98 & & & \\
\hline Source: Processed from company data & & & &
\end{tabular}

Based on PAM, wasteful activities in non-value-adding activities (NVA) take up $16.80 \%$ of the total processing time, which indicates the number of wasteful activities occurred during the production process. NVA is mostly caused by delay, while NNVA occurs at $1.44 \%$ of total production time.

TABLE 2: Average Lead Time.

\begin{tabular}{l|c|c|}
\hline Information & $\begin{array}{c}\text { Day's Physical } \\
\text { Stock }\end{array}$ & $\begin{array}{c}\text { Average Lead Time } \\
\text { (Days) }\end{array}$ \\
\hline Area of Raw Material & 1 & 75 \\
\hline Area of Production & 1 & 14 \\
\hline Area of Finished Goods & 2 & 42 \\
\hline Source: Processed from company data
\end{tabular}

Based on SCRM, the train car body production period, from purchasing raw materials to finishing, takes up 131 days. Day's physical stock shows the average of days in which raw materials are processed. Day's physical stock value in the raw material area 1 means that raw materials arrive from vendor to logistics division, then they are brought to the fabrication workshop at the same day. Day's physical stock in production area 1 indicates that the component is finished and moved to be assembled into train car body. Day's physical stock at the finished goods area 2 shows that train car body is assembled. Then, it must go through a reforming and inspection process first, before being moved to the finishing stage. 


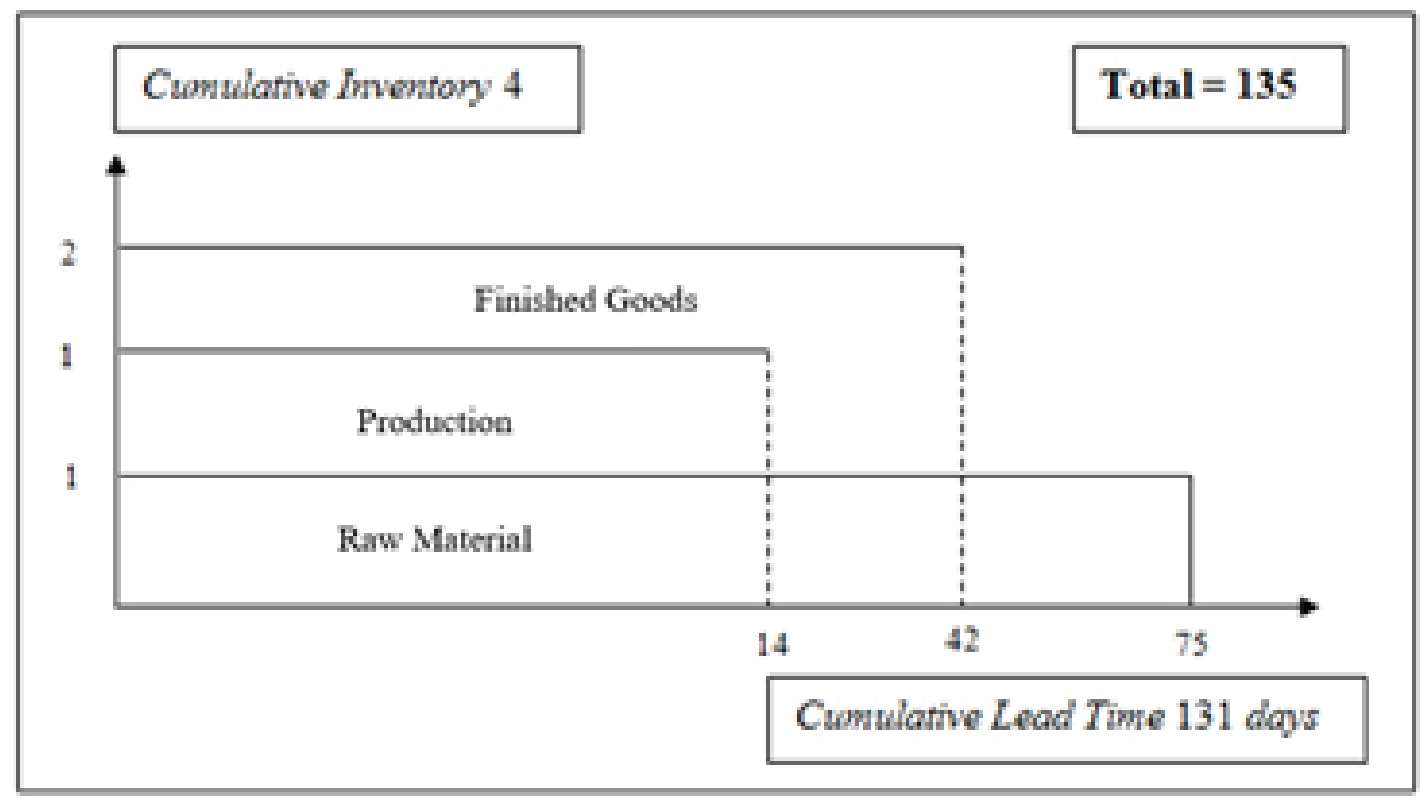

Figure 2: Cumulative Lead Time (Source: Processed from company data).

\subsubsection{Fishbone diagram}

Root cause analysis of problems with fishbone diagram was only conducted for four categories, namely man, method, material and machine, to further refine the previous analysis results. In the category of man, wastefulness occurred due to lack of skill and lack of training among the workforces. From the method category, wastefulness was caused by the delay of MD and DD, as well as raw material purchase procedures. From material category, wastefulness occurs, because raw materials are frequently late in delivery. Lastly, for machine, wastefulness occurs due to machines' frequent damage and it takes a while to purchase their spare parts from abroad.

\subsection{Suggestion for improvement}

\subsubsection{Future state mapping}

Formulation of the Future State Mapping is done by discussing the ideal production process desired by the company. Together with the informants, the authors discussed any non-value-adding activity (NVA) that might be reduced or even eliminated through Process Activity Mapping (PAM) analysis. Based on Future State Mapping, ideal condition desired by the company is the lack of lead time, which is largely caused by delay activity. Total VA is obtained from total operating time plus set-up time. The following is a table depicting PAM calculations with some reduced or eliminated NVA. 
TABLE 3: Suggestions for Improvement in Wasteful Activities.

\begin{tabular}{|c|c|}
\hline Type of Wasteful Activities & Suggestions for Improvement \\
\hline \multirow[t]{3}{*}{ Waiting period } & $\begin{array}{l}\text { 1. Schedule the arrival of materials and prepare for } \\
\text { some alternatives in terms of raw materials, in case } \\
\text { the suppliers are unable to fulfill the order, so that the } \\
\text { production process will not be delayed for too long. }\end{array}$ \\
\hline & $\begin{array}{l}\text { 2. Establish good communication with the suppliers, } \\
\text { particularly about the delivery time of raw materials }\end{array}$ \\
\hline & $\begin{array}{l}\text { 3. If the production time is too close to deadline, then } \\
\text { PT. INKA can purchase semi-finished raw materials } \\
\text { abroad to complete the orders faster. It might be } \\
\text { expensive, but it is better than paying a fine in case } \\
\text { PT. INKA is unable to fulfill the order on time. }\end{array}$ \\
\hline \multirow[t]{2}{*}{ Unnecessary Inventory } & $\begin{array}{l}\text { 1. Improve material handling and scrap removal. When } \\
\text { ready-made components and materials to be used in } \\
\text { production are neatly arranged in place, then the } \\
\text { available space will be sufficient to store what should } \\
\text { be stored on land. }\end{array}$ \\
\hline & $\begin{array}{l}\text { 2. Provide a warehouse or additional space to } \\
\text { anticipate the occurrence of delays in taking } \\
\text { components to the next workmanship. }\end{array}$ \\
\hline \multirow[t]{2}{*}{ Transportation } & $\begin{array}{l}\text { 1. Increase the number of hauling vehicles or forklifts } \\
\text { to move materials or components from one workshop } \\
\text { to another. }\end{array}$ \\
\hline & $\begin{array}{l}\text { 2. Material handling and appropriate scrap removal } \\
\text { will also facilitate the flow of transportation within the } \\
\text { plant. }\end{array}$ \\
\hline
\end{tabular}

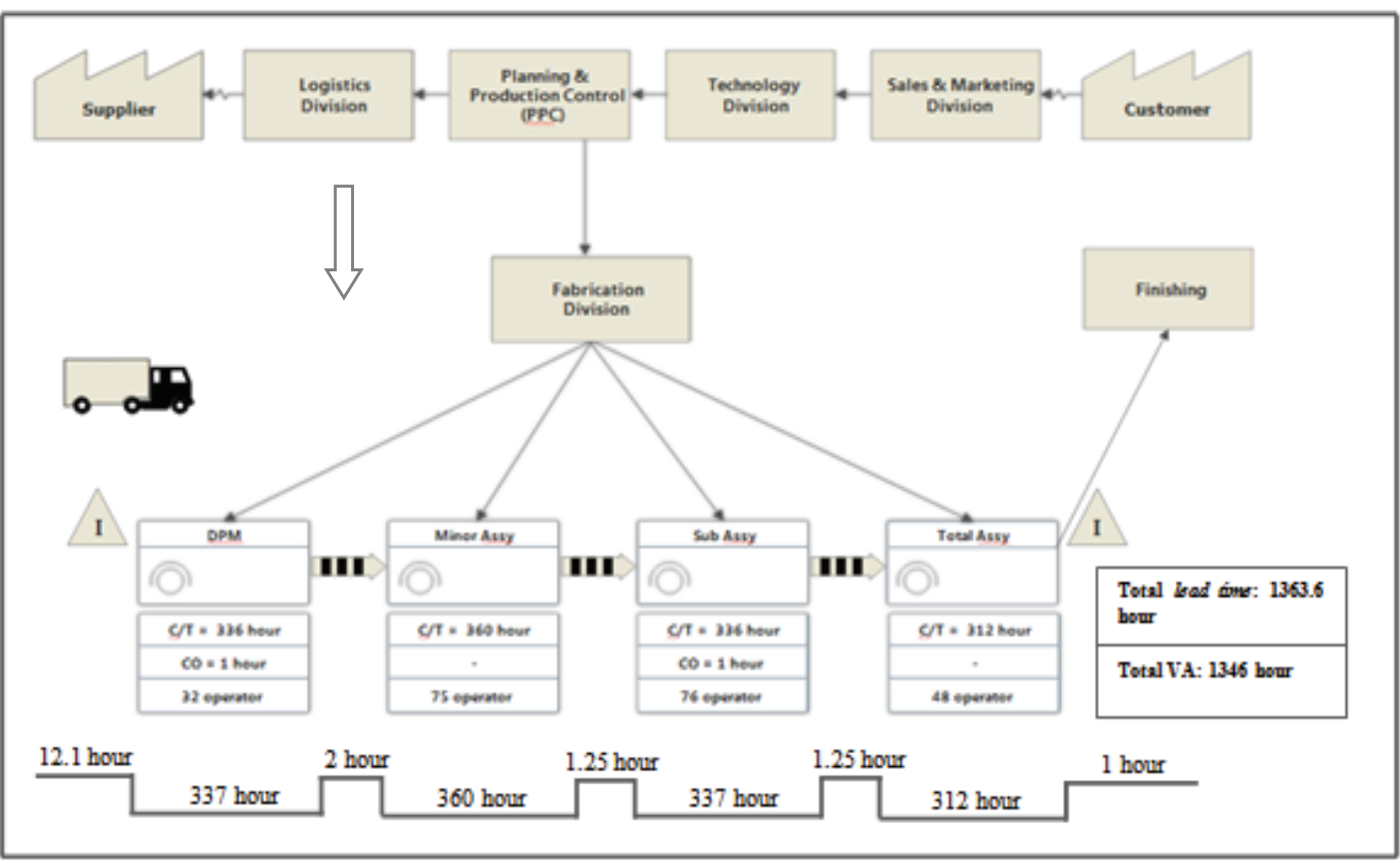

Figure 3: Future State Mapping (Source: Processed from company data). 
TABLE 4: Suggestions for Improvement to PT. INKA.

Categories
Man
1. Establish BLK or cooperate with BLK to conduct training on
employees with sufficient frequency, both for permanent
employees and outsourced employees. Training is expected to
improve the ability of individual employees equally.
2. Establish an organization for employees to facilitate post-work
activities, such as development of interests and talents. This
facility is expected to bring the employees closer to one another.
1. Prepare appropriate and detailed scheduling for each
production process, from raw materials to finished goods.
2. Maintain good communication with all divisions, especially
related to publishing manufacturing drawing (MD) and drawing
design (DD), so that the production process can run on time.
3. Develop a responsive plan to address sudden changes in
demand or in the middle of the production process.
1. Replace frequently damaged or unseemly machineries with
new ones whose capacities are in accordance with produced
outputs.
2. Conduct regular maintenance.
Machine

TABLE 5: Future State Mapping Results.

\begin{tabular}{l|c|c|c|c|}
\hline Activities & Number & $\begin{array}{c}\text { Percentage } \\
(\%)\end{array}$ & $\begin{array}{c}\text { Time } \\
\text { (hours) }\end{array}$ & $\begin{array}{c}\text { Percentage } \\
(\%)\end{array}$ \\
\hline Operation & 32 & $62.75 \%$ & 1321 & $96.88 \%$ \\
\hline Transportation & 12 & $23.53 \%$ & 5.5 & $0.40 \%$ \\
\hline Inspection & 3 & $5.88 \%$ & 26 & $1.91 \%$ \\
\hline Storing & 0 & $0.00 \%$ & 0 & $0.00 \%$ \\
\hline Delay & 4 & $7.84 \%$ & 11.1 & $0.81 \%$ \\
\hline Total & 51 & & 1363.6 & \\
\hline VA & 33 & $64.71 \%$ & 1321.5 & $96.91 \%$ \\
\hline NVA & 12 & $23.53 \%$ & 30.75 & $2.26 \%$ \\
\hline NNVA & 6 & $11.76 \%$ & 11.35 & $0.83 \%$ \\
\hline Total & 51 & & 1363.6 & \\
\hline Total time (hours) & 1363.6 & & & \\
\hline Total distance (meter) & 1394.98 & & & \\
\hline Source: Processed from company data & & &
\end{tabular}


Based on the table above, NVA activities and lead time are reduced. This is due to the reduction of delay or waiting time during the production process. The reduction of delay activity is conducted by starting the production process using the existing raw materials first, replacing the damaged machinery, minimizing the error rate at DPM, and increasing the number of conveyances. Comparison of actual condition and planned conditions for the future can be seen in the following table.

TABLE 6: Comparison of Mapping Results.

\begin{tabular}{l|c|c|c|}
\hline Remarks & $\begin{array}{c}\text { Current State } \\
\text { Map }\end{array}$ & Future State Map & $\begin{array}{c}\text { Increase in } \\
\text { Percentage }\end{array}$ \\
\hline Transportation & 5.75 hours & 5.5 hours & 4.34 \\
\hline Storing & 24 hours & o hour & 100 \\
\hline Delay & 239.6 hours & 11.1 hours & 95.36 \\
\hline NVA & 271.5 hours & 30.75 hours & 88.67 \\
\hline Lead Time & 1616.35 hours & 1363.6 hours & 15.64 \\
\hline Source: Processed from company data & &
\end{tabular}

Based on the table above, the improvement of production process occurred in transportation, storing and delay-related activities, as it affected the reduction of nonvalue-adding activity (NVA), amounted to 240.75 hours or equivalent to 10 days, which indicated an increase in the production process improvement of $88.67 \%$. Reduction of lead time also occurred at 252.75 hours or equivalent to 10.5 days, which indicated a $15.64 \%$ improvement. Significant improvement will improve the company performance, because the company can optimize its resources. It also increases the effectiveness and efficiency of its production process.

\section{Conclusions and Suggestions}

\subsection{Conclusions}

Based on the results of discussion and analysis in the previous chapter, the following conclusions can be drawn:

1. Identification of wastefulness was conducted using a weighted-questionnaire distributed to seven employees at PT. INKA as the informants who had the authority and understanding of the production process. The respondents consisted of employees from Fabrication, Planning and Control of Production, and Quality Control (QC). Based on the questionnaire results, the highest wastefulness was recorded by waiting time at $22.52 \%$, unnecessary inventory at $18.75 \%$ and transportation at $14.98 \%$. 
2. Wasteful waiting time was caused by the delay in the arrival of raw materials, so that the production process could not be started. It was followed by the storage of unnecessary inventory, which was caused by a lack of space to store materials or components. Wasted transportation is caused by ineffective displacement process due to lack of transport or forklift vehicles.

3. Waste analysis was conducted by selecting VALSAT tools with the highest value, named Process Activity Mapping (PAM) of 76.17 and Supply Chain Response Matrix (SCRM) of 44.1.

4. Based on PAM, the occurrence of wasteful and non-value-added activities (NVA) takes up 271.5 hours or $16.80 \%$ of total production time. NVA is mostly caused by delays that occur for several reasons, namely the amount of waiting time due to damaged engine or less precision in the process, while, based on SCRM, the total lead time was 131 days with cumulative inventory of four.

5. The analysis of the wasteful activities' root cause was also done using fishbone diagram with four categories. 'Man' category indicates lack of manpower skills due to lack of training. 'Method' category shows DD and MD are frequently late. 'Machine' category displays that the machines are frequently damaged, and their capacity is not in accordance with the output to be generated. 'Material' category indicates that the delivery of raw materials from the suppliers is frequently late.

\subsection{Suggestions}

Based on the research findings, we propose these suggestions for PT. INKA:

1. PT. INKA should provide sufficient training to employees who are involved in the production process, especially new employees, in order to have adequate and balanced skills among employees. The training should be conducted together with more experienced employees to avoid inequality of skills when the shift changes. In addition, an outsourcing process to attain a more skilled employee could save production costs, because work can be done better, rather than having to hire a large number of workforces near the deadline.

2. Because the arrival of raw materials is often delayed, PT. INKA should prepare alternative raw materials from other suppliers and maintain good communication with suppliers regarding delivery schedules. PT. INKA also should have some stocks of raw materials which are difficult to obtain or take a long time to purchase. 
3. If the production period is too close to deadline, PT. INKA should purchase semifinished raw materials to accelerate the production process. Although they might be expensive, the price is arguably less than the per-day fine PT. INKA needs to pay if it cannot fulfill an order.

As for academicians or further research, we suggest the following possible themes:

1. Preparation of Future State Mapping should be done after the company applies Lean Manufacturing in the production process to see significant results between past conditions and current conditions. Limitation of this research was that the Future State Mapping was not applied when the company had implemented Lean Manufacturing. In addition, there was inadequacy in the required data, so that problem analysis could not be done perfectly.

2. Future researchers are further advised to conduct further research on wastefulness using data which are not available in PT. INKA, so that the research will be more robust.

\section{References}

[1] Gasperz, Vincent. (2002). Manajemen Kualitas dalam Industri Jasa. Edisi Pertama. Jakarta: PT. Gramedia Pustaka Utama.

[2] Hines, P., \& Nick Rich. (1997). The Seven Value Stream Mapping Tools. International Journal of Operations \& Production, Vol. 16 (1-2): 46-55.

[3] Jacobs, F. R., \& Chase, R. B. (2011). Operations and Supply Chain Management. $13^{\text {th }}$ ed. Global Edition. New York: McGraw-Hill/Irwin series.

[4] Liker, J. (2006). The Toyota Way: 14 Prinsip Manajemen dari Perusahaan Manufaktur Terhebat di Dunia. Penerbit Erlangga.

[5] Sugiyono. (2005). Memahami Penelitian Kualitatif. Bandung: ALFABET.

[6] Womack, J. P., \& Jones, D. T. 2003. Lean Thinking: Banish Waste and Create Wealth in Your Corporation. Simon \& Schuster.

[7] https://www.bps.go.id/linkTableDinamis/view/id/815 